\title{
Algengi fæouofnæmis hjá íslenskum börnum á fyrsta ári
}

\section{Ágrip}

Kristinsdóttir $^{1}$

læknanemi

Michael Clausen ${ }^{2}$

barna- og ofnæmislæknir

Hildur S.

Ragnarsdóttir ${ }^{3}$

hjúkrunarfræðingur

Ingibjörg H.

Halldórsdóttir ${ }^{3}$

líffræðingur

\section{Doreen McBride ${ }^{4}$}

sérfræðingur

Kirsten Beyer ${ }^{5}$

barna-, ofnæmis- og

ónæmislæknir

Sigurveig $\mathbf{P}$. Sigurðardóttir ${ }^{1,3}$

barna-, ofnæmis- og ónæmislæknir

Lykilorð: börn, fæðuofnæmi, algengi, astmi.

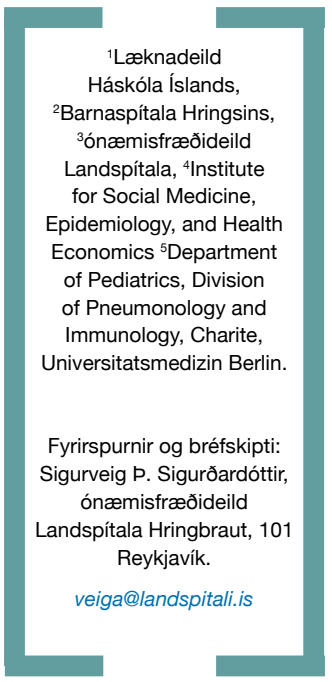

Inngangur: Rannsóknin er hluti af alpjóðlegri fæðuofnæmisrannsókn, EuroPrevall. Markmiðið var að rannsaka algengi fæðuofnæmis hjá íslenskum börnum á fyrsta ári.

Efniviður og aðferðir: Börnum (n=1341) var fylgt eftir frá fæðingu til eins árs aldurs. Spurningalistar voru lagðir fyrir við fæðingu og 12 mánaða aldur. Barn með einkenni fæðuofnæmis var skoðað af rannsóknarlækni, ofnæmishúðpróf gerð og sértækt IgE mælt. Fæðuofnæmi var staðfest eða afsannað með tvíblindu polprófi.

Niðurstöður: Alls kom 231 barn í læknisheimsókn. Fjörutíu og fjögur börn (3,27\%) voru með jákvæð ofnæmispróf, par af 21 (1,57\%) með jákvætt húðpróf og 40 (2,98\%) með sértækt IgE í sermi. Fæðuofnæmi var staðfest hjá 25 börnum $(1,86 \%)$. Algengi ofnæmis fyrir eggjum var $1,42 \%$; mjólk 0,52\%; fiski 0,22\%; hveiti 0,15\%; jarðhnetum $0,15 \%$ og soja $0,07 \%$. Exem var greint hjá $7,90 \%$ $(\mathrm{n}=106)$ og samkvæmt spurningalista voru $8,80 \%$ með astma $(\mathrm{n}=118)$. Jákvæð fjölskyldusaga var sterkasti áhættupátturinn fyrir astma $(\mathrm{OR}=2,12$; $\mathrm{p}<0,001)$ og exemi $(\mathrm{OR}=1,90 ; \mathrm{p}=0,004)$. Fylgni var á milli áhættupátta og ofnæmissjúkdóma innan fjölskyldna.

Ályktun: Niðurstöðurnar sýna heldur lægri tíðni en fyrri rannsókn á fæouofnæmi hjá íslenskum börnum á öðru ári. Pær sýna einnig lægri tíðni fæðuofnæmis en í sumum öðrum Evrópulöndum sem hugsanlega má rekja til erfða og umhverfispátta.

\section{Inngangur}

Fáar framskyggnar rannsóknir hafa verið gerðar í Evrópu á fæðuofnæmi barna frá fæðingu. EuroPrevall-hóprannsóknin er samevrópskt verkefni sem varpar á ljósi á eðli og algengi fæðuofnæmis hjá börnum í Evrópu frá fæðingu til 30 mánaða aldurs.

Margar rannsóknir hafa áætlað algengi fæðuofnæmis. Ekki er ljóst hvort mismunandi greiningaraðferðir, landfræðilegur eða erfðafræðilegur munur eða allt petta veldur mismunandi niðurstöðum. Rannsóknir par sem IgE-miðlað fæðuofnæmi var sannað með polprófum sýna $1-4,2 \%$ algengi hjá börnum (1-11 ára) en $0,8-3,2 \%$ hjá fullorðnum. ${ }^{1}$ Um 4-38\% einstaklinga telja sig hafa fæðuofnæmi. ${ }^{1}$ Mismunandi niðurstöður og greiningaraðferðir gera samanburð erfiðan og kalla á nýja fjölpjóðarannsókn byggða á stöðluðum aðferðum.

Myndun fæðuofnæmis er talin ráðast af samspili erfða og umhverfis. Fjölbreytileiki sem tengist fæðuofnæmi hefur fundist í níu genum. ${ }^{2}$ Ekki er vitað hvaða umhverfispættir skipta máli." ${ }^{4}$ Раð hefur verið talið verndandi að gefa börnum eingöngu brjóstamjólk og ekki fastan mat fyrr en eftir sex mánaða aldur. ${ }^{5}$ Petta hefur líka verið dregið í efa. ${ }^{4,6}$ Eftir að Alpjóðaheilbrigðisstofnunin (WHO) ráðlagði brjóstamjólk til 4-6 mánaða aldurs hefur fæðuofnæmi aukist í hinum vestræna heimi. ${ }^{6}$

Markmið pessa hluta EuroPrevall-rannsóknarinnar var að rannsaka algengi fæðuofnæmis hjá íslenskum börnum á fyrsta ári og jafnframt að skoða algengi barnaexems og astma. Einnig voru skoðuð tengsl umhverfis og ofnæmissjúkdóma foreldra við ofnæmissjúkdóma barna.

\section{Efni og aôferöir}

Lýsing á aðferðum EuroPrevall-rannsóknarinnar hefur verið birt og par má lesa nánar um pær. ${ }^{7}$

Pessi rannsókn var framskyggn ferilrannsókn. Pátttakendur voru 1341 barn og foreldrar peirra sem uppfylltu eftirfarandi pátttökuskilyrði: skriflegt upplýst sampykki foreldra, meðganga 34 vikur eða lengur og lífsmarkaskor (APGAR) sjö stig eða hærra eftir fimm mínútur frá fæðingu. Auk pess purfti móðir að hafa málskilning til að skilja inntak rannsóknarinnar. Persónuvernd og Vísindasiðanefnd sampykktu rannsóknina í september 2005. Pátttakenda var aflað frá október 2005 til júní 2008. Barnshafandi konur fengu upplýsingar um rannsóknina í mæðraeftirlitinu eða á fósturgreiningardeild Landspítala. Eftir fæðingu barns var hringt í móður pess og lagður fyrir hana staðlaður spurningalisti.

Börnunum var fylgt eftir í 12 mánuði frá fæðingu. Premur, sex og níu mánuðum eftir fæðingu var haft samband við móður og minnt á einkenni fæðuofnæmis og mikilvægi pess að hafa samband ef pau kæmu fram. Dæmi um einkenni voru 
Tafla I. Ástæða komu barns til rannsóknarlæknis.

\begin{tabular}{|c|c|c|}
\hline \multirow[t]{2}{*}{ Ástæða komu til læknis ${ }^{a}$} & \multicolumn{2}{|c|}{ Fjöldi barna } \\
\hline & $n$ & $\%(n / 1341)^{b}$ \\
\hline Exem & 124 & $9,25 \%$ \\
\hline Grunur um fæðuofnæmi & 74 & $5,52 \%$ \\
\hline Einkenni frá meltingarvegi & 43 & $3,21 \%$ \\
\hline Ofsakláđi & 23 & $1,72 \%$ \\
\hline Einkenni frá öndunarvegi & 7 & $0,52 \%$ \\
\hline Viðmiðunarbörn & 61 & $4,55 \%$ \\
\hline
\end{tabular}

aÁstæðurnar gátu verið fleiri en ein hjá hverju barni.

${ }^{\mathrm{b}}$ Miðað við fjölda pátttakenda. voru notaðar til að ákvarða algengi astma á fyrsta ári. Spurt var hvort læknir hefði á síðustu 12 mánuðum greint astma hjá barninu. Einnig var spurt hvort barnið hefði haft hvæsandi öndun eða píphljóð í brjósti, hvort komið hefði hvæsandi hljóð úr brjóstkassa við eða eftir áreynslu og hvort barnið hefði verið með purran hósta um nætur án pess að hafa kvef eða sýkingu í brjóstholi. Einnig var spurt um notkun berkjuvíkkandi lyfja og innöndunarstera.

Við rannsóknina störfuðu barnalæknir sem er sérfræðingur í ofnæmislækningum og hjúkrunarfræðingur og sáu pau alfarið um allar skoðanir og ofnæmispróf.

Ef barn var með ofnæmisexem var notað SCORAD-kerfið (Scoring Atopic Dermatitis) til að ákvarða alvarleika.

Í ofnæmishúðprófi var prófað fyrir mjólk, eggjum, hveiti, soja, fiski og jarðhnetum og auk pess hundum, köttum og grasi. Pvermál bjúgbletts sem var stærra eða jafnt og prír millimetrar sagði til um jákvætt próf.

Heilblóð (4-5 ml) var tekið úr börnum með einkenni fæðuofnæmis og viðmiðunarbörnum til mælingar á sértæku IgE fyrir eggjum, mjólk, jarðhnetum, soja, hveiti og fiski. Prófið var jákvætt ef svarið var $>0,35 \mathrm{kUA} / 1$. Ef grunur var um ofnæmi fyrir annarri fæðutegund en prófað var fyrir var mælt IgE og gert húopróf sérstaklega fyrir pá fæðutegund. barn kallað til skoðunar. Spurningar um astma

Hringt var í pátttakendur 12 mánuðum eftir fæðingu og lagður fyrir staðlaður spurningalisti. Ef foreldrar svöruðu jákvætt spurningum um

Tafla II. Fjöldi barna með fæðuofnæmi eftir tegund ofnæmisprófs og ofnæmisvaldi.

\begin{tabular}{|c|c|c|c|c|c|c|}
\hline Ofnæmisvaldur & $\begin{array}{c}\text { Grunur um } \\
\text { fæðuofnæmi }\end{array}$ & $\begin{array}{c}\text { Jákvætt ofnæmis- } \\
\text { húđpróf }\end{array}$ & $\begin{array}{l}\text { Jákvætt lgE í } \\
\text { sermi }\end{array}$ & Næm börn & $\begin{array}{c}\text { Jákvætt tvíblint } \\
\text { polpróf }^{c}\end{array}$ & $\begin{array}{c}\text { Grunur á móti } \\
\text { greindu }^{d}\end{array}$ \\
\hline Egg & $7(0,52 \%)^{e}$ & $17(1,27 \%)$ & $29(2,16 \%)$ & $32(2,38 \%)$ & $19(1,42 \%)$ & $4 / 4$ \\
\hline Mjólk & $56(4,18 \%)$ & $10(0,75 \%)$ & $23(1,72 \%)$ & $24(1,79 \%)$ & $7(0,52 \%)$ & $23 / 7$ \\
\hline Jarðhnetur & & $3(0,22 \%)$ & $9(0,67 \%)$ & $9(0,67 \%)$ & $2(0,15 \%)$ & \\
\hline Fiskur & $5(0,37 \%)$ & $1(0,07 \%)$ & $2(0,15 \%)$ & $2(0,15 \%)$ & $3(0,22 \%)$ & $0 / 0^{f}$ \\
\hline Hveiti & $7(0,52 \%)$ & 0 & $8(0,16 \%)$ & $8(0,60 \%)$ & $2(0,15 \%)$ & $0 / 0^{f}$ \\
\hline Soja & $2(0,15 \%)$ & 0 & $4(0,30 \%)$ & $4(0,30 \%)$ & $1(0,07 \%)$ & $1 / 0$ \\
\hline Rækjur & $1(0,07 \%)$ & & & & & \\
\hline Trönuber & $1(0,07 \%)$ & & & & & \\
\hline Kartöflur & $2(0,15 \%)$ & & & & & \\
\hline Ananas & $1(0,07 \%)$ & & & & & \\
\hline Möndlur & $1(0,07 \%)$ & $1(0,07 \%)$ & & $1(0,07 \%)$ & & \\
\hline Nutramigen & $1(0,07 \%)$ & & & & & \\
\hline Grænar baunir & & & $1(0,07 \%)^{g}$ & $1(0,07 \%)$ & & \\
\hline \multicolumn{7}{|c|}{ 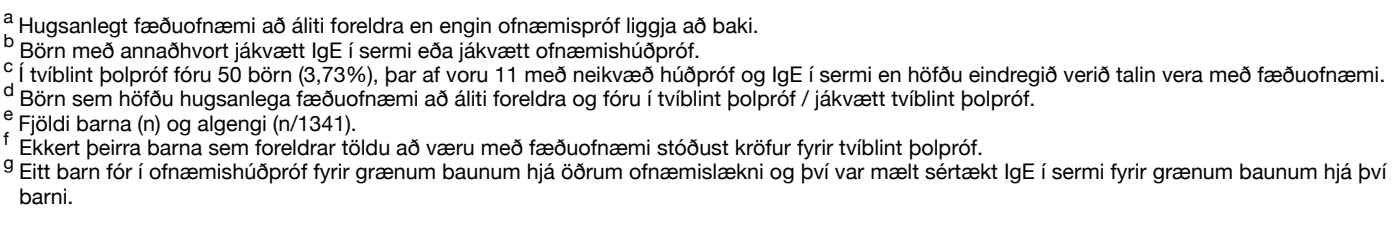 } \\
\hline
\end{tabular}


Staðfest fæðuofnæmi var skilgreint sem jákvætt tvíblint polpróf. Tvíblind polpróf fyrir mjólk voru framkvæmd á öllum aldri en fyrir annarri fæðu eftir sex mánaða aldur, nema fyrir jarðhnetum, fiski og skelfiski sem voru framkvæmd eftir 12 mánaða aldur.

Fyrir hvert barn sem uppfyllti kröfur um tvíblint polpróf voru tvö heilbrigð börn án ofnæmiseinkenna beðin um að koma í skoðun. Barn fætt á undan og á eftir barni með einkenni voru tekin sem viðmið.

Hjá viðmiðunarbörnunum var framkvæmd líkamsskoðun, tekinn spurningalisti og blóðsýni. Ef barn í viðmiðunarhópi fékk seinna einkenni fæðuofnæmis var pað skilgreint sem barn með einkenni og var pá sjálft parað á sama hátt við tvö heilbrigð viðmiðunarbörn.

Tengsl milli ofnæmissjúkdóma og umhverfispátta eða jákvæðrar fjölskyldusögu voru skoðuð með pví að setja hugsanlega áhættupætti og afleiðingu upp í krosstöflu. Reiknaðar voru hlutfallslegar líkur (OR) á milli pessara pátta með 95\% öryggismörkum. P-gildi var reiknað með kí-kvaðrati ( $\chi^{2}$ prófi) og tölfræðilega marktækt p-gildi var sett við <0,05. Pætti sem skoðaðir voru má sjá í töflu III. Ofnæmissjúkdómar sem bornir voru saman við hugsanlega áhættupætti voru staðfest fæðuofnæmi, exem, astmi, næming, jákvætt ofnæmishúðpróf og jákvætt IgE í sermi. Með næmingu er átt við annaðhvort jákvætt IgE í sermi eða jákvætt ofnæmishúðpróf.

Allir tölfræðiútreikningar voru gerðir í SPSS tölfræðiforritinu útgáfu 11,5 (SPSS Inc, Chicago, USA).

\section{Niðurstöður}

Pátttakendur sem uppfylltu öll pátttökuskilyrði voru 1345. Par af voru fjórir einstaklingar brottfluttir og 27 einstaklingar luku ekki við rannsóknina. Alls var 1314 einstaklingum fylgt eftir í 12 mánuði frá fæðingu.

Mæður barnanna voru á aldrinum 16-45 ára og var meðalaldur peirra 30 ár. Feðurnir voru 19-63 ára, meðalaldur 32 ár. Stúlkubörn voru 655 (48,84\%). Barn var að meðaltali í sex mánuði og sex daga á brjósti. Spurningalistum svöruðu 1338 mæður eftir fæðingu og 1151 við 12 mánaða aldur. Mismunurinn liggur í pví að ekki náđist að taka viðtal við alla foreldra við 12 mánaða aldur.

Tilkynningar um ofnæmiseinkenni voru 426, par af tilkynntu 44 mæður tvisvar um ofnæmiseinkenni hjá sama barni $(3,28 \%)$. Til rannsóknarlæknis komu 170 börn (12,68\%) og af peim komu 26 tvisvar. Sextíu og eitt viðmiðunarbarn kom í skoðun. Ástæður fyrir læknisheimsókn

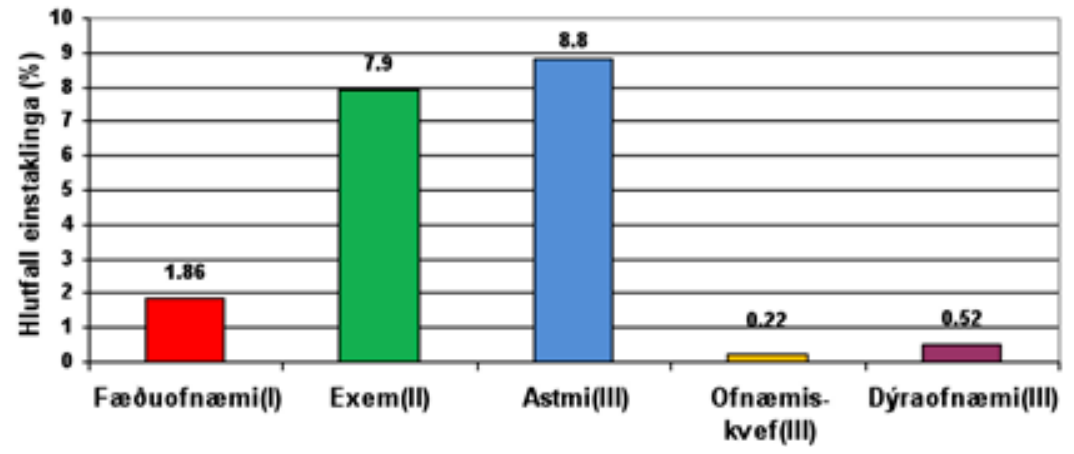

Mynd 1. Algengi ofnæmissjúkdóma samkvæmt greiningu læknis.

I. Staðfest með tvíblindu polprófi.

II. Samkvæmt greiningu rannsóknarlæknis.

III. Samkvæmt niðurstöðum spurningalista par sem móðir var spurð hvort læknir hefði greint barn hennar með ofnæmissjúkdóm á fyrstu 12 mánuðunum frá fæðingu.

sjást í töflu I. Tafla II sýnir fæðutegundir sem foreldrar töldu að yllu ofnæmi. Eftir læknisheimsókn voru 7,90\% barnanna greind með exem $(106 / 1341)$ og 3,28\% talin vera með fæðuofnæmi (44/1341). Í læknisheimsókn var gert ofnæmishúðpróf hjá 156 börnum (11,63\%). Tuttugu og eitt barn var með jákvætt ofnæmishúðpróf (1,57\%). Dreifingu jákvæðra ofnæmishúðprófa eftir fæðuofnæmisvaldi má sjá í töflu II.

Tekin var blóðprufa úr öllum viðmiðunarbörnunum og 153 börnum með ofnæmiseinkenni, alls úr 214 börnum (15,96\%). Börn með jákvætt IgE í sermi fyrir helstu mótefnisvökum í fæðu voru 40 (2,98\%). Ekkert viðmiðunarbarn var með jákvætt IgE. Dreifing jákvæðs IgE sést í töflu II.

Næm börn voru 44 (3,27\%). Dreifing næmingar eftir ofnæmisvaldi sést í töflu II.

Í tvíblint polpróf fóru 50 börn (3,73\%), par af voru 11 með neikvæð húðpróf og IgE í sermi en sterkan grun um fæðuofnæmi samkvæmt sögu. Tuttugu og fimm börn voru með jákvætt polpróf $(1,86 \%)$. Fjórtán voru með ofnæmi fyrir einni fæðutegund (ellefu fyrir eggjum, tvö fyrir mjólk og eitt fyrir jarðhnetum). Tvö af peim voru hvorki með jákvætt IgE í sermi né húðpróf en staðfest fæðuofnæmi fyrir mjólk og eggjum. Sjö börn voru með ofnæmi fyrir tveimur fæðutegundum (sex fyrir mjólk og eggjum og eitt fyrir jarðhnetum og soja). Tvö börn voru með ofnæmi fyrir premur fæðutegundum (annað fyrir eggjum, mjólk og fiski og hitt fyrir eggjum, mjólk og jarðhnetum). Tvö börn voru með ofnæmi fyrir fjórum fæðutegundum (fyrir eggjum, mjólk, fiski og hveiti). Staðfest algengi fæðuofnæmis hjá börnum á fyrsta ári er pví 1,86\% (25/1341).

Samkvæmt spurningalista við 12 mánaða aldur voru $0,22 \%$ barna greind af lækni með ofnæmiskvef (3/1341); 0,52\% greind með dýraofnæmi (7/1341) og 8,80\% greind með astma (118/1341), sjá mynd 
Tafla III. Hugsanlegir áhættupættir.

\begin{tabular}{|c|c|c|c|c|}
\hline \multirow[t]{2}{*}{ Hugsanlegur áhættupáttur } & \multicolumn{2}{|c|}{ Samtals fjöldi } & \multicolumn{2}{|c|}{$\begin{array}{l}\text { Börn með fæðuofnæmi } \\
\text { samkvæmt polprófi }\end{array}$} \\
\hline & $\mathrm{N}$ & $\begin{array}{c}\% \\
(N / 1341)\end{array}$ & $\mathrm{n}$ & $\begin{array}{c}\% \\
(n / 25)\end{array}$ \\
\hline Fæðing barns með valkeisara eđa bráđakeisara & 170 & $12,68 \%$ & 5 & $20 \%$ \\
\hline Barn: sýklalyf á fyrstu vikunni & 85 & $6,33 \%$ & 2 & $8 \%$ \\
\hline Barn: súrefni međan á sjúkrahúsdvöl stóð & 129 & $9,62 \%$ & 3 & $12 \%$ \\
\hline Móðir: sýklalyf í fæðingunni & 135 & $10,07 \%$ & 4 & $16 \%$ \\
\hline Móðir: sýklalyf eftir fæðinguna & 80 & $5,97 \%$ & 1 & $4 \%$ \\
\hline Móðir: sýklalyf á meðgöngu & 312 & $23,27 \%$ & 5 & $20 \%$ \\
\hline Barn: ábót í sjúkrahúsdvöl & 413 & $30,80 \%$ & 8 & $32 \%$ \\
\hline Móđir: á sér sögu um ofnæmi* & 656 & $48,91 \%$ & 12 & $48 \%$ \\
\hline Fađir: á sér sögu um ofnæmi & 521 & $38,85 \%$ & 14 & $56 \%$ \\
\hline Foreldrar eiga sér sögu um ofnæmi ${ }^{*}$ & 255 & $19,02 \%$ & 7 & $28 \%$ \\
\hline Móðir: meðgöngueitrun & 75 & $5,59 \%$ & 1 & $4 \%$ \\
\hline Móðir: háprýstingur á međgöngu & 141 & $10,52 \%$ & 3 & $12 \%$ \\
\hline Móðir: meðgöngusykursýki & 34 & $2,54 \%$ & 1 & $4 \%$ \\
\hline Móðir: pvagfærasýking á meðgöngu & 138 & $10,29 \%$ & 0 & $0 \%$ \\
\hline Móðir: kvef/hiti á meðgöngu & 420 & $31,32 \%$ & 0 & $0 \%$ \\
\hline Báđir foreldrar með háskólagráđu & 424 & $31,62 \%$ & 11 & $44 \%$ \\
\hline Móðir reykti á meðgöngu & 103 & $7,68 \%$ & 0 & $0 \%$ \\
\hline Móðir: óbeinar reykingar á meðgöngu & 84 & $6,26 \%$ & 1 & $4 \%$ \\
\hline Barn: óbeinar reykingar & 437 & $32,59 \%$ & 8 & $32 \%$ \\
\hline Gæludýr á heimilinu & 376 & $28,04 \%$ & 9 & $36 \%$ \\
\hline Móðir: lýsi að staðaldri á meðgöngu & 495 & $37,14 \%$ & 8 & $32 \%$ \\
\hline $\begin{array}{l}\text { Móðir: lýsi að staðaldri pegar hún var með barn } \\
\text { á brjósti }\end{array}$ & 401 & $29,90 \%$ & 7 & $28 \%$ \\
\hline Barn: lýsi daglega eða oft í viku & 937 & $69,87 \%$ & 14 & $56 \%$ \\
\hline
\end{tabular}

1. Af peim börnum sem greind voru með astma höfðu 88,98\% (104/118) haft hvæsandi öndun eða píphljóð í brjósti og 84,74\% (100/118) fengið berkjuvíkkandi lyf og stera í innöndun.

Heildarhlutfall barna með ofnæmissjúkdómana astma, exem, ofnæmiskvef eða staðfest fæðuofnæmi á fyrsta ári er 15,96\% (214/1341).

Rannsakaðir voru áhættupættir sem gætu haft áhrif á tilkomu ofnæmissjúkdóma hjá barni, sjá töflu III. Tafla IV sýnir pá áhættupætti par sem hugsanleg fylgni fannst.

Meðgöngueitrun hjá móður jók tilhneigingu barns til að mynda næmi fyrir fæðu ( $p=0,002$; $\mathrm{OR}=3,42(95 \%$ CI 1,47-7,95)) en sú fylgni hvarf ef móðir hafði aldrei verið með ofnæmi.

Lýsisneysla barns, daglega eða oft í viku, minnkaði líkur á að pað yrði næmt fyrir fæðu $(p=0,005 ; \quad O R=0,42 \quad(95 \%$ CI $0,22-0,79))$, fengi jákvætt ofnæmishúðpróf ( $\mathrm{p}=0,025 ; \mathrm{OR}=0,39$ (95\% CI 0,16-0,92)) og jákvætt IgE í sermi ( $p=0,010$; $\mathrm{OR}=0,46$ (95\% CI 0,25-0,84)) en jók tilhneigingu til astma ( $\mathrm{p}=0,002 ; \mathrm{OR}=2,12$ (95\% CI 1,29-3,43)). Pessi fylgni hvarf ef foreldrar barns höfðu aldrei verið með ofnæmi.

Reykingar á meðgöngu minnkuðu líkur á pví að barn fengi exem ( $\mathrm{p}=0,021 ; \mathrm{OR}=0,22$ (95\% CI 0,05-0,90)) og átti pað líka við ef móðir hafði aldrei fengið ofnæmi ( $p=0,047 ; O R=0)$. Hins vegar var ekki fylgni milli pessara pátta ef foreldrar áttu sér sögu um ofnæmi.

Mæður sem höfðu fengið ofnæmi voru 48,9\% og feður 38,9\%. Par af höfðu 6,3\% foreldra ofnæmi fyrir hundum, 9,6\% fyrir köttum og 7\% fyrir ryki. Sterkasti áhættupátturinn fyrir astma var ef foreldrar höfðu fengið ofnæmi ( $\mathrm{p}<0,001 ; \mathrm{OR}=2,12$ $(95 \%$ CI 1,40-3,21)) og exem $(\mathrm{p}=0,004 ; \mathrm{OR}=1,90$ (95\% CI 1,22-2,97)). Ef eingöngu móðir átti sér sögu um ofnæmi var barn hennar líklegra til að fá astma ( $\mathrm{p}=0,001 ; \mathrm{OR}=1,99(95 \%$ CI 1,34-2,95)) en pað hafði ekki áhrif á exem. Ef aðeins faðir hafði fengið ofnæmi var barn hans líklegra til að fá exem ( $\mathrm{p}=0,024 ; \mathrm{OR}=1,58$ (95\% CI 1,06-2,36)) en pað hafði ekki áhrif á astma.

\section{Umræơur}

Niðurstöðurnar varpa ljósi á algengi fæðuofnæmis, astma og exems á fyrsta ári og sýna algengustu fæðutegundir sem valda ofnæmi hjá pessum aldurshópi. Pær undirstrika nauðsyn pess að greina fæðuofnæmi rétt til að hlífa barni við sjúkdómsvaldandi fæðu, en einnig að nauðsynlegt er að sanna fæðuofnæmið til að ofgreina ekki.

Af peim 1345 börnum sem upphaflega hófu pátttöku, luku 1314 við 12 mánaða eftirfylgni og er úrtaksrýrnun pví lítil á pessu tímabili.

Pátttakendur í rannsókninni eru um 13,4\% af peim börnum sem fæddust á sömu svæðum og á sama tímabili. ${ }^{8}$ I öllum svona rannsóknum er hætta á valskekkju, en hátt hlutfall foreldra sem eiga sér sögu um ofnæmi (mæður 48,9\% og feður $38,8 \%$ ) gæti bent til pess. Engar birtar tölur eru til um ofnæmi fullorðinna Íslendinga, athugað með spurningalistum. Til að athuga valskekkju bárum við sögu um staðfest ofnæmi hjá foreldrum saman við rannsókn Davíðs Gíslasonar frá 1995 á 20-44 ára gömlum Íslendingum. ${ }^{9}$ Rannsóknin sýndi jákvætt húðpróf fyrir hundum hjá 6,3\%, köttum hjá 7,6\% og rykmaurum hjá $6,1 \%$, sem er sambærilegt við okkar rannsókn sem skoðaði sögu um staðfest ofnæmi. ${ }^{9}$

Í rannsókn okkar töldu 5,52\% mæðra barn sitt vera með fæðuofnæmi. Í íslenskri rannsókn á 18 mánaða gömlum börnum töldu $27 \%$ foreldra 
$(86 / 324)$ að barn sitt hefði fæðuofnæmi ${ }^{10}$ og rannsókn frá Isle of Wight í Englandi á börnum á fyrsta ári sýndi að 7,2\% (65/900) foreldra taldi barn sitt hafa fæðuofnæmi. ${ }^{11}$ Lægra hlutfall í okkar rannsókn gæti verið vegna pess að við komu til rannsóknarlæknis voru einkenni flokkuð samkvæmt lýsingu frá móður sem hugsanlegt fæðuofnæmi, exem, einkenni frá meltingarvegi, einkenni frá öndunarvegi eða ofsakláði. Fæðuofnæmi gat legið að baki einkennum frá húð, meltingar- og öndunarvegi en var ekki flokkað sem slíkt nema sterkur grunur væri um að einkenni versnuðu við að borða viðkomandi fæðu.

Rannsóknin sýnir að 7,90\% barna á fyrsta ári eru með exem samkvæmt sjúkrasögu og líkamsskoðun. Spurningar sem fjalla um astma og astmaeinkenni benda til að algengi astma sé $8,80 \%$. Flest barnanna höfðu haft hvæsandi öndun eða píphljóð í brjósti $(88,98 \%)$ og verið á bæði berkjuvíkkandi lyfi og innöndunarsterum $(84,74 \%)$. Okkur gæti hafa yfirsést átta börn með pessari aðferð par sem mæður sögðu barn sitt hafa verið með einkenni astma, fengið berkjuvíkkandi lyf og innöndunarstera en neituðu astmagreiningu samkvæmt lækni. Ekki eru til eldri tölur um algengi astma og exems á fyrsta ári hjá íslenskum börnum en tölur eru til fyrir 18-23 mánaða börn. ${ }^{12}$ Sú rannsókn sýndi 31\% (56/179) algengi exems og 19\% algengi astma (34/179). Rannsókn okkar sýnir lægra algengi en algengi ofnæmissjúkdóma er að aukast fyrstu ár ævinnar og gæti pað skýrt pennan mun. ${ }^{13}$

Tvö börn með staðfest fæðuofnæmi, fyrir mjólk sem olli niðurgangi og fyrir eggjum sem gerðu exem verra, voru ekki næm samkvæmt húoprófi eða IgE í sermi. Ástæðan fyrir pví gæti verið ópol eða annars konar ofnæmissvar, til dæmis af týpu IV.

Næming barna fyrir fæðu var 3,27\% (44/1341). Rannsókn okkar er framskyggn tilfellaviðmiðuð ferilrannsókn sem pýðir að börn sem ekki fengu einkenni fæðuofnæmis eða voru valin í viðmiðunarhóp voru ekki skimuð með ofnæmishúðprófum eða sértæku IgE. Í slíkri rannsókn er næming barna og jafnvel fæðuofnæmi hugsanlega vanmetið par sem ekki hafa öll börn fengið pá fæðu sem pau eru næm fyrir. Ekkert viðmiðunarbarn var með jákvætt IgE innan við 12 mánaða aldur sem styrkir niðurstöður okkar. Engar fyrri rannsóknir hafa skoðað næmi á fyrsta aldursári íslenskra barna en rannsókn frá Isle of Wight ${ }^{11}$ frá árinu 2006 sýndi að næming barna á fyrsta ári fyrir helstu mótefnavökum í fæðu var 2,2\% (17/763), sem er nokkru lægra en okkar niðurstöður. Pessi rannsókn notaðist við sambærileg greiningarpróf og okkar rannsókn. Í peirri rannsókn var algengi
Tafla IV. Marktæk fylgni milli áhættupátta og staðfestra ofnæmissjúkdóma.

\begin{tabular}{|c|c|c|c|c|c|c|}
\hline Áhættupáttur & Næming & $\begin{array}{l}\text { Jákvætt } \\
\text { lgE í sermi }\end{array}$ & $\begin{array}{l}\text { Jákvætt } \\
\text { húðpróf }\end{array}$ & Astmi & Exem & $\begin{array}{l}\text { Ofnæmis- } \\
\text { kvef }\end{array}$ \\
\hline $\begin{array}{l}\text { Móðir fékk } \\
\text { meðgöngueitrun }\end{array}$ & $\begin{array}{l}\mathrm{p}=0,002 \\
\mathrm{OR}=3,42\end{array}$ & & & & & \\
\hline $\begin{array}{l}\text { Barn fékk lýsi } \\
\text { daglega eða oft } \\
\text { i viku }\end{array}$ & $\begin{array}{l}\mathrm{p}=0,005 \\
\mathrm{OR}=0,42\end{array}$ & $\begin{array}{l}p=0,010 \\
O R=0,46\end{array}$ & $\begin{array}{l}\mathrm{p}=0,025 \\
\mathrm{OR}=0,39\end{array}$ & $\begin{array}{l}P=0,002 \\
O R=2,12\end{array}$ & & \\
\hline $\begin{array}{l}\text { Móðir reykti á } \\
\text { meðgöngu }\end{array}$ & & & & & $\begin{array}{l}p=0,021 \\
O R=0,22\end{array}$ & \\
\hline $\begin{array}{l}\text { Bádir foreldar } \\
\text { eiga sér sögu um } \\
\text { ofnæmi }\end{array}$ & & & & $\begin{array}{l}p<0,001 \\
O R=2,12\end{array}$ & $\begin{array}{l}p=0,004 \\
O R=1,90\end{array}$ & \\
\hline $\begin{array}{l}\text { Móđir á sér sögu } \\
\text { um ofnæmi }\end{array}$ & & & & $\begin{array}{l}p=0,001 \\
O R=1,99\end{array}$ & & \\
\hline $\begin{array}{l}\text { Fađir á sér sögu } \\
\text { um ofnæmi }\end{array}$ & & & & & $\begin{array}{l}p=0,024 \\
O R=1,58\end{array}$ & \\
\hline
\end{tabular}

Taflan sýnir áhættupætti par sem fylgni fannst við ofnæmissjúkdóma hjá barni. Fylltir reitir merkja að par voru ómarktækar niðurstöður. Ekki fannst fylgni milli pessara áhættupátta og ofnæmissjúkdóma hjá barni ef foreldrar höfðu ekki ofnæmissjúkdóma.

staðfests fæðuofnæmis 1,5\% (15/969) og er pað einnig lægra en okkar rannsókn gaf $(1,86 \%)$.

Rannsókn á 18 mánaða gömlum íslenskum börnum notaði svipaðar aðferðir við ofnæmisgreiningu og notaðar voru í rannsókn okkar ${ }^{10}$ en mældi ekki sértækt IgE í blóði. Sú rannsókn sýndi að 2\% barna voru með staðfest fæðuofnæmi (7/324). Er pað mjög sambærilegt við okkar niðurstöður og munurinn gæti skýrst af aldursmun barnanna.

Ef við berum okkar niðurstöður um næmingu saman við rannsókn frá árinu 1992, pá sýndi sú rannsókn að 39\% 18-23 mánaða íslenskra barna voru næm fyrir einhverjum ofnæmisvaka. ${ }^{14}$ Petta er allnokkru hærra gildi en rannsókn okkar sýnir en benda má á prennt í pví sambandi. Í fyrsta lagi voru ekki mældir sömu mótefnavakar par sem í fyrri rannsókninni var mælt sértækt IgE fyrir mjólk, eggjum, fiski, ketti, ryki og grasi. Í öðru lagi miðar sú rannsókn jákvæðar mælingar á $\operatorname{IgE}$ í sermi við >0,23 kUA/1 en okkar rannsókn miðar við IgE magn $>0,35 \mathrm{kUA} / 1$. Í priðja lagi er okkar úrtak yngri börn. Ef skoðaður er fjöldi barna með jákvætt ofnæmispróf fyrir hverja fæðutegund, eftir

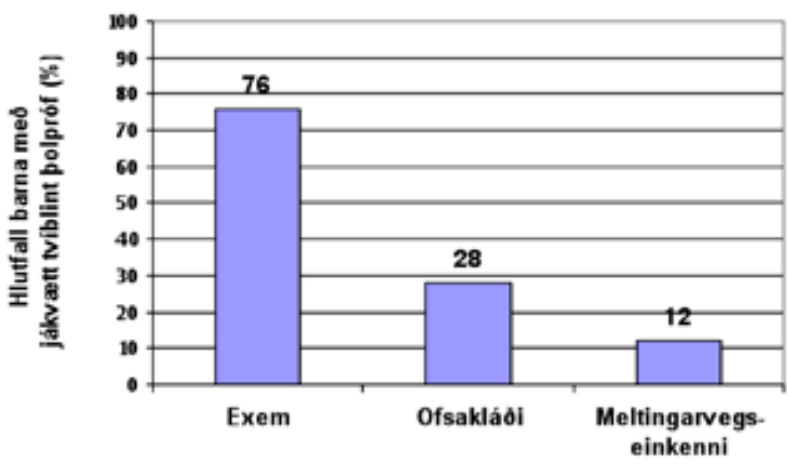

Mynd 2. Einkenni barna sem voru með staðfest fæðuofnæmi. Myndin sýnir einkenni sem foreldrar barna með staðfest fæðuofnæmi greindu frá pegar pau komu ískoðun til rannsóknarlæknis. 
tegund ofnæmisprófa, sést að egg, jarðhnetur og mjólk eru algengustu ofnæmisvaldarnir (sjá töflu II). Petta samræmist vel peim fæðutegundum sem áður hafa verið taldar helstu ofnæmisvaldar í börnum. $5,10,15$

Exem var langalgengasta einkenni peirra barna sem voru með jákvætt polpróf (sjá mynd 2) sem er í samræmi við fyrri rannsóknir.11,16

Tafla III sýnir hugsanlega áhættupætti sem við athuguðum sérstaklega.

Talið er að snerting við bakteríuflóru í leggöngum móður hafi áhrif á ónæmiskerfi barna. ${ }^{17}$ Rannsókn okkar sýndi ekki auknar líkur á ofnæmissjúkdómum hjá börnum sem fæddust með keisaraskurði. Rannsókn frá Noregi á tveggja ára börnum sýndi ekki auknar líkur á fæðuofnæmi en auknar líkur á astma hjá peim sem höfðu fæðst með keisaraskurði. ${ }^{17}$ Sýklalyf hafa á sama hátt áhrif á bakteríuflóruna. Rannsókn par sem börnum var fylgt eftir frá fæðingu sýndi auknar líkur á astma og exemi ef móðir fékk sýklalyf á öðrum eða priðja priðjungi meðgöngu. ${ }^{18}$ Okkar rannsókn studdi ekki pessar niðurstöður.

Súrefni gefið eftir fæðingu hefur verið tengt aukinni hættu á astma á fyrstu 10 árum ævinnar. ${ }^{19}$ Engin tengsl fundust í okkar rannsókn, sem getur skýrst af stuttum eftirfylgnitíma.

Niðurstöður rannsókna á áhrifum ábótar á ofnæmi hjá barni hafa ekki verið samhljóða. ${ }^{20}$ Ábót á meðan sjúkrahúsdvöl stóð hafði ekki áhrif á ofnæmi hjá barni í okkar rannsókn.

Í Boston Birth Cohort-rannsókninni tengdist meðgöngusykursýki ofnæmisexemi, næmingu fyrir fæðu (eggjahvítu, mjólk, jarðhnetum, rækjum, hveiti og valhnetum) og loftbornum ofnæmisvökum pegar fylgt var eftir í 3,2 ár. ${ }^{21}$ Rannsókn okkar studdi ekki pessar niðurstöður, sem gæti skýrst af styttri eftirfylgnitíma.

Rannsókn okkar staðfesti niðurstöður annarrar rannsóknar sem sýndi að pvagfærasýking, sýking í leggöngum, sýking í efri loftvegi eða meltingarfærasýking á meðgöngu tengdust ekki ofnæmisexemi í börnum. ${ }^{22}$

Rannsókn gerð í Stokkhólmi á fjögurra ára börnum sýndi minni hættu á astma, ofnæmiskvefi og næmingu fyrir mótefnavökum í fæðu með hærri pjóðfélagsstétt foreldra sem metin var út frá atvinnu. ${ }^{23}$ Rannsókn okkar sýndi ekki fylgni eftir menntun foreldra. Yfirlitsgrein frá árinu 2010 sýndi ekki sterk tengsl á milli áhrifa gæludýra á tilkomu ofnæmissjúkdóma og pað sama á við um okkar rannsókn. ${ }^{24}$

Sýnt hefur verið fram á að stress hjá móður á meðgöngu og í fæðingu eykur áhættuna á astma og ofnæmi hjá barni. ${ }^{25}$ Niðurstöður okkar eru 1 samræmi við niðurstöður rannsóknar sem sýndi auknar líkur á næmingu (kettir, hundar, hestar, birki, vallarfoxgras, búrót, rykmaurar) hjá 15-17 ára unglingum ef móðir peirra hafði fengið meðgöngueitrun. ${ }^{25}$

Lýsisneysla daglega eða oft í viku minnkaði tilhneigingu til næmingar fyrir fæðu en jók tilhneigingu til astma. Rannsókn frá Prándheimi sem skoðaði áhrif lýsistöku á meðgöngu og eftir fæðingu barns á astma og exem á öðru ári, sýndi verndandi áhrif lýsis fyrir exemi. ${ }^{26}$

Minni líkur voru hjá barni að fá exem ef móðir reykti á meðgöngu. Pessar niðurstöður ber pó að taka með peim fyrirvara að einungis tvö börn með exem voru útsett fyrir tóbaksreyk og pyrfti pví stærra pýði til að fá afgerandi niðurstöður. Rannsóknir hafa sýnt fylgni á milli reykinga móður á meðgöngu og eftir fæðingu við astma hjá barni. ${ }^{27}$ Rannsókn okkar styður ekki pá fylgni en algengi astma eykst með hækkandi aldri.

Ef foreldrar áttu sér hvorugt sögu um ofnæmi hafði pað ekki áhrif á fylgni milli ofangreindra áhættupátta og ofnæmissjúkdóma hjá barni. Раð bendir til að tengsl á milli áhættupátta og ofnæmissjúkdóma hjá barni séu ekki einungis háð umhverfispáttum heldur líka fjölskyldusögu.

Jákvæð fjölskyldusaga hefur verið tengd við auknar líkur á að barn fái ofnæmissjúkdóm. Fundist hafa gen sem tengjast auknum líkum á exemi og er par helst að nefna gen sem kóðar fyrir filaggrin-próteininu í húð. ${ }^{28}$ Einnig hefur jákvæð fjölskyldusaga móður verið tengd við aukna hættu á astma hjá barni. ${ }^{29}$ Niðurstöður rannsóknar okkar staðfesta að fjölskyldusaga um ofnæmissjúkdóma hefur forspárgildi um ofnæmissjúkdóma hjá barni, pað er astma og exem. ${ }^{12}$ Rannsóknin sýndi að ofnæmissaga móður virðist auka líkurnar á astma hjá barni en ofnæmi föður virðist auka líkur á exemi.

\section{Ályktun}

Rannsókn okkar sýnir lægra algengi fæðuofnæmis, astma og exems á fyrsta ári en fyrri rannsóknir. Pátttakendur fyrri rannsókna á Íslandi eru pó eldri börn, 18 mánaða til tveggja ára. Algengi ofnæmissjúkdóma eykst fyrstu ár ævinnar, sem gæti skýrt pennan mun.

Niðurstöður okkar benda eindregið til að fjölskyldusaga eigi stóran pátt í tilkomu ofnæmis par sem umhverfispættir virtust eingöngu hafa áhrif á tíðni ofnæmissjúkdóma hjá barni ef mæður voru með ofnæmi sjálfar.

EuroPrevall-rannsóknin, sem er fjölpjóðleg rannsókn, mun svara með beinum samanburði við aðra pátttakendur í Evrópu hvort fæðuofnæmi er sjaldgæfara hér á landi og hvaða umhverfispættir 
stuðla að eða draga úr ofnæmissjúkdómum hjá börnum. Einnig fæst svar við pví hvort algengi fæðuofnæmis fer vaxandi hér á landi pegar börnunum verður fylgt eftir til 24 mánaða aldurs og samanburður fæst við fyrri rannsóknir.

Niðurstöður pessarar rannsóknar eru bæði áhugaverðar fyrir Ísland og í alpjóðlegu samhengi. Ráðgert er að fylgja pessum börnum eftir næst við sex ára aldur í áframhaldandi alpjóðlegu samstarfi.

\section{Pakkir}

Pakkir eru færðar peim fjölmörgu sem komu að pessari rannsókn; Önnu Guðbjörgu Gunnarsdóttur hjúkrunarfræðingi, öðrum starfsmönnum EuroPrevall-rannsóknarinnar á Íslandi og hjúkrunarfræðingum í mæðraeftirliti og fósturgreiningardeildum. Einnig fá öll börnin og foreldrarnir sem tóku pátt í rannsókninni pakkir. Að lokum fá Rannsóknarsjóður íslenskra námsmanna, vísindasjóður Landspítala og Evrópusambandið (FOOD-CT-2005-514000) pakkir fyrir að styrkja verkefnið.

\section{Heimildir}

1. Rona RJ, Keil T, Summers C, et al. The prevalence of food allergy: A meta-analysis. J Allergy Clin Immunol 2007; 120: 638-46.

2. Hong X, Tsai HJ, Wang X. Genetics of food allergy. Curr Opin Pediatr 2009; 21: 770-6.

3. van Wijk F, Knippels L. Initiating mechanisms of food allergy: Oral tolerance versus allergic sensitization. Biomed Pharmacother 2007; 61: 8-20.

4. Berg AV, Krämer U, Link E, et al. Impact of early feeding on childhood eczema: Development after nutritional intervention compared with the natural course - The GINIplus study up to the age of 6 years. Clin Exp Allergy 2010; 40: 627-36

5. Sicherer SH, Sampson HA. 9. Food allergy. J Allergy Clin Immunol 2006; 117(SUPPL. 2):S470-S5+S89.

6. Høst A, Halken S, Muraro A et al. Dietary prevention of allergic diseases in infants and small children: Amendment to previous published articles in Pediatric Allergy and Immunology 2004, by an expert group set up by the Section on Pediatrics, European Academy of Allergology and Clinical Immunology. Pediatr Allergy Immunol 2008; 19: 1-4.

7. Keil T, McBride D, Grimshaw K, et al. The multinational birth cohort of EuroPrevall: background, aims and methods. Allergy 2010; 65: 482-90.

8. Landlæknisembættið. Fæðingar á Íslandi og fæðingartíðni 1995-2009. www.influensa.is/Heilbrigdistolfraedi/Faedingar. 30. apríl 2010.

9. Gíslason D, Gíslason P, Blöndal P, Helgason H. Bráđaofnæmi hjá 20-44 ára Íslendingum. Læknablaðið 1995; 81: 606-12.

10. Kristjansson I, Ardal B, Jonsson JS, Sigurdsson JA, Foldevi $\mathrm{M}$, Bjorksten B. Adverse reactions to food and food allergy in young children in Iceland and Sweden. Scand J Prim Health Care 1999; 17: 30-4.
11. Venter C, Pereira B, Grundy J. et al. Incidence of parentally reported and clinically diagnosed food hypersensitivity in the first year of life. J Allergy Clin Immunol 2006; 117: 111824.

12. Eiríksson $\mathrm{H}$, Árdal $\mathrm{B}$, Lúðvíksson $\mathrm{BR}$, Sigfússon $\mathrm{A}$, Valdimarsson H, Haraldsson A. Ofnæmi og astmi hjá íslenskum börnum. Læknablaðið 2000; 86: 102-7.

13. Cantani A. The growing genetic links and the early onset of atopic diseases in children stress the unique role of the atopic march: a meta-analysis. J Investig Allergol Clin Immunol 1999; 9: 314-20.

14. Ludviksson BR, Eiriksson TH, Ardal B, Sigfusson A, Valdimarsson H.Correlation between serumimmunoglobulin A concentrations and allergic manifestations in infants. J Pediatrics 1992; 121: 23-7.

15. Osterballe M, Hansen TK, Mortz CG, Høst A, BindslevJensen $C$. The prevalence of food hypersensitivity in an unselected population of children and adults. Pediatr Allergy Immunol 2005; 16: 567-73.

16. Östblom E, Wickman M, van Hage M, Lilja G. Reported symptoms of food hypersensitivity and sensitization to common foods in 4-year-old children. Acta Paediatr 2008; 97: 85-90.

17. Kvenshagen B, Halvorsen R, Jacobsen M. Is there an increased frequency of food allergy in children delivered by caesarean section compared to those delivered vaginally? Acta Paediatr 2009; 98: 324-7.

18. Jedrychowski W, Galas A, Whyatt R, Perera F. The prenatal use of antibiotics and the development of allergic disease in one year old infants. A preliminary study. Int J Occup Med Environ Health 2006; 19: 70-6.

19. Martel MJ, Rey E, Malo JL, et al. Determinants of the incidence of childhood asthma: a two-stage case-control study. Am J Epidemiol 2009; 169: 195-205.

20. Grimshaw KE, Allen K, Edwards CA, et al. Infant feeding and allergy prevention: a review of current knowledge and recommendations. A EuroPrevall state of the art paper. Allergy 2009; 64: 1407-16.

21. Kumar R, Ouyang F, Story RE et al. Gestational diabetes, atopic dermatitis, and allergen sensitization in early childhood. J Allergy Clin Immunol 2009; 124: 1031-8.

22. Sugiyama M, Arakawa H, Ozawa K, et al. Early-life risk factors for occurrence of atopic dermatitis during the first year. Pediatrics 2007; 119: e716-23.

23. Almqvist C, Pershagen G, Wickman M. Low socioeconomic status as a risk factor for asthma, rhinitis and sensitization at 4 years in a birth cohort. Clin Exp Allergy 2005; 35: 612-8.

24. Chen CM, Tischer C, Schnappinger M, Heinrich J. The role of cats and dogs in asthma and allergy-a systematic review. Int J Hyg Environ Health 2010; 213: 1-31.

25. Keski-Nisula L, Heinonen S, Remes S, Pekkanen J. Preeclampsia, placental abruption and increased risk of atopic sensitization in male adolescent offspring. Am J Reprod Immunol 2009; 62: 293-300.

26. Oien T, Storro O, Johnsen R. Do early intake of fish and fish oil protect against eczema and doctor-diagnosed asthma at 2 years of age? A cohort study. J Epidemiol Community Health years of age? A

27. Davidson R, Roberts SE, Wotton CJ, Goldacre MJ. Influence of maternal and perinatal factors on subsequent hospitalisation for asthma in children: evidence from the Oxford record linkage study. BMC Pulm Med 2010; 10: 14.

28. Barnes KC. An update on the genetics of atopic dermatitis: scratching the surface in 2009. J Allergy Clin Immunol 2010; 125: 16-29 e1-11; quiz 30-1.

29. Pohlabeln $H$, Muhlenbruch $K$, Jacobs $S$, Bohmann $H$. Frequency of allergic diseases in 2-year-old children in relationship to parental history of allergy and breastfeeding. J Investig Allergol Clin Immunol 2010; 20: 195-200. 


\section{Prevalence of food allergy in Icelandic infants during first year of life}

Objective: This study is a part of EuroPrevall, an EU-funded European food allergy project. The aim was to evaluate the prevalence of food allergy in Icelandic infants during their first year of life.

Material and methods: Infants $(n=1,341)$ were followed prospectively from birth to 12 months of age. Questionnaires were obtained at birth and 12 months. Children with symptoms of possible food allergy were assessed with a skin-prick test (SPT) and specific lgE. Food allergy was confirmed with a double-blind placebocontrolled food challenge (DBPCFC).

Results: Out of 170 symptomatic children 44 infants (3.27\%) had either positive SPT $(n=21 ; 1.57 \%)$ or specific $\lg \mathrm{E}(\mathrm{n}=40 ; 2.98 \%)$. Food allergy was confirmed in 25
(1.86\%); egg allergy $1.42 \%$, milk $0.52 \%$, fish $0.22 \%$, wheat $0.15 \%$, peanuts $0.15 \%$, and soy $0.07 \%$. Atopic dermatitis was diagnosed in $7.90 \%(n=106)$ and according to questionnaires $8.80 \%$ had asthma $(n=118)$. Positive family history was the strongest risk factor for asthma $(\mathrm{OR}=2.12$; $p<0.001)$ and atopic dermatitis $(O R=1.90 ; p=0.004)$. Family history influenced the relationship between predisposing factors and allergy symptoms.

Conclusion: Our results show lower prevalence of food allergy than previously reported in a study of Icelandic children at two years of age. The prevalence was also lower than reported in some other European countries and could be explained by different genetic and environmental factors.

Kristinsdóttir H, Clausen M, Ragnarsdóttir HS, Halldórsdóttir IH, McBride D, Beyer K, Sigurðardóttir ST

Prevalence of food allergy in Icelandic infants during first year of life. Icel Med J 2011; 97: 11-8

Key words: exem, infants, food allergy, prevalence, asthma, atopic dermatitis.

Correspondence: Sigurveig P. Sigurðardóttir, veiga@landspitali.is

Barst: 25. maí 2010, - sampykkt til birtingar: 9. nóvember 2010 Hagsmunatengsl: Engin 